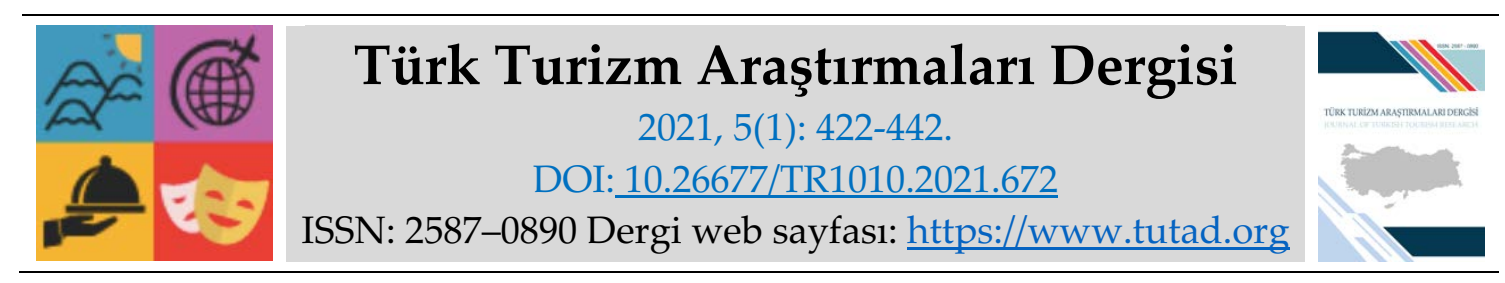

ARASTTIRMA MAKALESI

\title{
Otel Çalışanlarının İşkoliklik ve Yenilikçi İş Anlayışı Düzeylerinin İş Tatminleri Üzerindeki Etkisinin İncelenmesi
}

Dr. Öğr. Üyesi Fatih VAROL, Selçuk Üniversitesi, Turizm Fakültesi, Konya, e-posta: fvarol@selcuk.edu.tr ORCID: https://orcid.org/0000-0002-0258-5220

Dr. Öğr. Üyesi Erhan KILINÇ, Selçuk Üniversitesi, Beyşehir Ali Akkanat İşletme Fakültesi, Konya, e-posta: erhankilinc@selcuk.edu.tr

ORCID: https://orcid.org/0000-0002-2065-2407

Öz

Bu çalışmanın amacı, otel çalışanlarının işkoliklik ve yenilikçi iş anlayışı düzeylerinin iş tatmini üzerindeki etkisini incelemektir. Ayrıca otel çalışanlarının sosyo-demografik özellikleri ile işkoliklik, yenilikçi iş anlayışı ve iş tatmini düzeyleri üzerinde farklılıklar olup olmadığı ortaya konulmaya çalışılmıştır. Bu amaç doğrultusunda, Konya' da faaliyet gösteren dört ve beş yıldızlı otel çalışanlarına yönelik anket çalışması yapılmıştır. Araştırma sonuçlarına göre katılımcıların genel işkoliklik 3,4900 \pm 0,76751 (min:1-mak:5), yenilikçi iş anlayışı düzeyleri 3,9652 $\pm 0,69410$

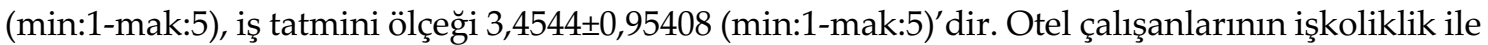
yenilikçi iş anlayışı arasında; işkoliklik ile iş tatmini arasında ve yenilikçi iş anlayışı ile iş tatmini arasında aynı yönlü ve orta düzey bir ilişki saptanmışır. Ayrıca otel çalışanların işkoliklik düzeylerinin ve yenilikçi iş anlayışı düzeylerinin iş tatmini üzerinde pozitif ve anlamlı bir etkiye sahip olduğu görülmektedir. İşkolikliğin iş tatmininin \%21,40'lık kısmını; yenilikçi iş anlayışının da iş tatmininin \%23,7'lik kısmını açıkladığı görülmektedir.

Anahtar Kelimeler: İşkoliklik, Yenilikçi İş Anlayışı, İş tatmini, Otel Çalışanları.

Makale Gönderme Tarihi: 30.10.2020

Makale Kabul Tarihi: 08.03.2021

\section{Önerilen Atıf:}

Varol, F. ve Kılınç, E. (2021). Otel Çalışanlarının İşkoliklik ve Yenilikçi İş Anlayışı Düzeylerinin İş Tatminleri Üzerindeki Etkisinin İncelenmesi, Türk Turizm Araştırmaları Dergisi, 5(1): 422-442. (C) 2021 Türk Turizm Araştırmaları Dergisi. 


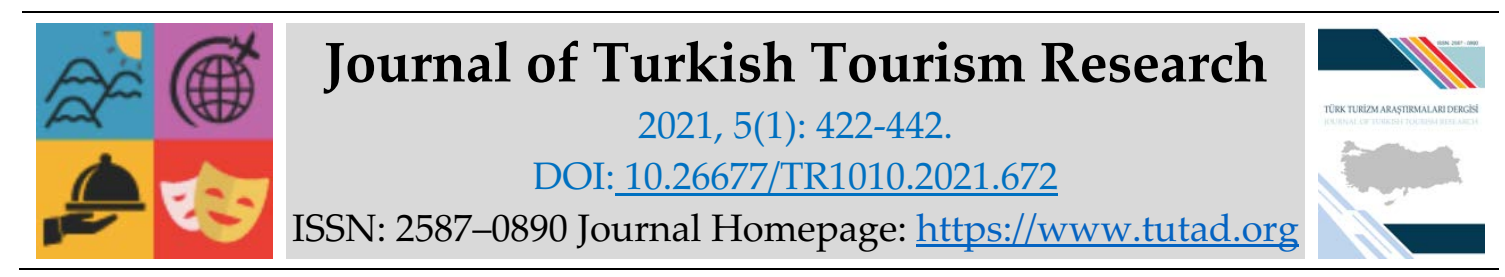

\title{
$\underline{\text { RESEARCH PAPER }}$
}

\section{Investigation of the Effect of Hotel Employees' Workaholism and Innovative Work}

Assistant Prof. Dr. Fatih VAROL, Selçuk University, Faculty of Tourism, Konya, e-mail: fvarol@selcuk.edu.tr

ORCID: https://orcid.org/0000-0002-0258-5220

Assistant Prof. Dr. Erhan KILINÇ, Selçuk University, Beyşehir Ali Akkanat Faculty of Business, Konya, e-mail: erhankilinc@selcuk.edu.tr

ORCID: https://orcid.org/0000-0002-2065-2407

\begin{abstract}
The purpose of this study is to examine the effect of workaholic and innovative work behavior levels of hotel staff on job satisfaction. In addition, it has been tried to reveal whether there are differences between the socio-demographic characteristics of hotel employees and their workaholism, innovative work behavior and job satisfaction levels. For this purpose, a survey has been conducted for four- and five-star hotel employees operating in Konya. According to the results of the research, the general workaholism of the participants is $3.4900 \pm 0.76751$ (min: 1max: 5), their level of innovative work behavior is $3.9652 \pm 0.69410$ (min: 1-max: 5), job satisfaction scale is $3.4544 \pm 0.95408$ (min: 1-max: 5). A similar and medium-level relationship has been found between hotel employees' workaholism and their innovative work behavior, between workaholism and their job satisfaction, and between their innovative business mentality and their job satisfaction. In addition, it is seen that the workaholism levels and innovative work behavior of hotel employees have a positive and significant effect on job satisfaction. $21.40 \%$ of the job satisfaction of the workaholism; it is seen that innovative work behavior explains $23.7 \%$ of job satisfaction.
\end{abstract}

Keywords: Workaholism, Innovative Work Behavior, Job Satisfaction, Hotel Employees.

Received: 30.10 .2020

Accepted: 08.03.2021

\section{Suggested Citation:}

Varol, F. and K1lınç, E. (2021). Investigation of the Effect of Hotel Employees' Workaholism and Innovative Work, Journal of Turkish Tourism Research, 5(1): 422-442.

(c) 2021 Türk Turizm Araştırmaları Dergisi. 


\section{GİRIŞ}

Emek-yoğun hizmet sunan işletmelerin başında gelen otel işletmelerinde yüksek hizmet kalitesi, büyük ölçüde çalışanların sergilediği performansa bağlıdır. Bu durum özellikle rekabetin yoğun olduğu bölgelerde daha da önemlidir. Bu nedenle oteller, zorlu çalışma koşullarının üstesinden gelmek ve müşterilerin çeşitli ihtiyaçlarını karşılamak için işine bağlı, özverili, yenilikçi ve proaktif çalışanlara ihtiyaç duymaktadır (Walz ve Niehoff, 2000; He vd., 2011; Dhar, 2015; Jung ve Yoon, 2016). Bununla birlikte değişen ve gelişen turizm sektöründe otel müşterilerinin kaliteli konaklama hizmeti deneyimi beklentisinin ve algısının "ürün" yerine "yenilikçi faaliyetlere" kaydığ 1 da görülmektedir. Bunun en önemli nedeni ise, artık belirli bir doyum noktasına ulaşan konaklama işletmesi müşterilerinin kalite odağının sunulan ürün ve hizmetten ziyade, beklentilerinin karşılanması yönünde değişmesidir (Işık ve Meriç, 2015). Bu noktada, diğer birçok işletmede olduğu gibi otel işletmelerinin de yoğun rekabet karşısında ayakta kalmaları ve avantaj sağlamaları, yenilikçi ve yaratıcı bir iş yaklaşımından ve özverili bir çalışmadan geçmektedir. Bu durum, konaklama sektöründe güncel konular arasına girmiş olan işkoliklik ve yenilikçi iş anlayışı ile iş tatmini kavramlarını ortaya çıkarmaktadır.

Değişen ve küreselleşen iş dünyasındaki ekonomik faaliyetler ve teknoloji dünyasındaki hızlı gelişmeler, çalışma koşullarındaki esneklik imkânlarının sürekli artması ile birlikte, iş görenlerin kariyer isteğinin yaygınlaşması ve işverenlerin çalışanlardan daha çok iş üretme beklentisi gibi bazı durum ve gelişmeleri beraberinde getirmiştir. Bu durum, beraberinde 'işkoliklik' olarak adlandırılan ve çalışanlar üzerinde isteyerek/istemeyerek daha çok iş ve işyeri ile zaman geçirme durumunu ortaya koyan bir kavramı literatüre kazandırmıştır. İşletmelerde işkoliklik durumunu yaşayan çalışanların işleri ile ilgili uzun, yorucu ve yoğun saatler yaşadıkları görülmektedir (van Beek vd., 2011). Kastner'a (2010) göre, önemli olan çalışanların sadece performansı değil, aynı zamanda refahıdır. Günümüzde çalışanlara yönlendirilen aşırı iş talepleri, onlarda tükenmişlik ve stres durumu yaşatmaktadır. Bu nedenle, işletmelerde faaliyet gösteren çalışanların neredeyse tamamına yakını, refahları için zararlı olan stres sorunlarıyla karşı karşıya kalmaktadırlar. Scottl vd. (1997) göre, işkoliklik hakkında çok şey yazılmış olmasına rağmen, konuyla ilgili titiz araştırma ve teorik geliştirme henüz başlangıç aşamasındadır. Onlara göre üç tür işkolik davranış kalıbı bulunmaktadır. Bunlar; kompulsif bağımlı, mükemmeliyetçi ve başarıya yönelik işkolikliktir. Her tür işkoliklik modeli ile performans, iş ve yaşam memnuniyeti ve işten ayrılma niyeti gibi önemli sonuçlar arasında potansiyel bağlantılar bulunmaktadır. İşkolik davranış örüntüsünün türüne bağlı olarak, işkolikliğin iyi ya da kötü olabileceğini ve sonuçlarının bireyler, kuruluşlar ve genel olarak toplum tarafından farklı şekilde deneyimlenebileceği veya değerlendirilebileceği sonucuna varılmıştır.

Yenilikçi iş anlayışı kavramı, örgüt çalışanlarının yenilikçi fikirleri geliştirmesine, bu fikirleri ürün ve süreçler olarak somutlaştırabilmesine dair tutum ve becerilerini ifade eden davranışlar olarak tanımlanabilmektedir. İşletmelerin değişen iç ve dış çevre koşullarına uyum sağlayabilmeleri için, tedarik aşamasından satış sonrasındaki hizmetlere kadar, sürekli yenilikleri takip etmeleri ve bunu bir kültür haline getirmeleri gerekmektedir. Bunun için, örgütlerin kendilerini daha esnek ve daha dinamik bir yapıya dönüştürmeleri gerekmektedir. İşletmeler arasında giderek artan yoğun rekabet ve bunun sonucunda çalışanların yenilikçi davranışlarının daha da önem kazanması hem işletmeler hem de araştırmacılar için geniş ve güncel bir konu olan yenilikçi iş anlayışı kavramının ortaya çıkmasına neden olmuştur (Tang vd., 2019). İşletmelerde yeni fikirlerin başarılı bir şekilde uygulanması, işletme süreçlerini iyileştirilmesi, pazara yeni ve geliştirilmiş ürün ve hizmetler sunabilmesi, verimliliğini artırabilmesi ve en önemlisi karlılığını artırabilmesi için oldukça önem arz etmektedir. Bu çalışmada, otel işletmesi çalışanlarının işkoliklik ve yenilikçi iş anlayışı düzeylerinin iş tatmini üzerindeki etkisinin belirlenmesi amaçlanmaktadır. 


\section{KAVRAMSAL ÇERÇEVE}

\section{İşkoliklik}

Günümüz iş dünyasında, küresel ekonominin baskılarından ve eş zamanlı olarak iş kariyerleri noktasında çalışanları ödüllendirmeyi sevk eden bir rekabet anlayışının "işkoliklik" kavramını ortaya çıkardığ1 söylenmektedir (Blair-Loy ve Jacobs, 2003). İşkoliklik kavramının ortaya çıkmasında önemli olan bir diğer neden ise, işverenlerin iş görenlerden daha fazla çalışma beklentileri ve gelişen teknoloji ile birlikte (Drago, 2000; Frese, 2008) artık işlerin mobil cihazlar (telefon, tablet, laptop vs.) sayesinde (Blair-Loy ve Jacobs, 2003) her yerde (özellikle evde) çalışmaya imkân vermesidir (Schabracq ve Cooper, 2000). Bu değişiklik, çalışanları ezici bir çoğunlukla işlerine katılmaya ve ayrıca uzun saatler çalışmaya teşvik etmiştir (van Wijhe vd., 2011). İş bağımlılı̆̆ı olarak da adlandırılan "işkoliklik" kavramı, özellikle 2000'li yılların başından itibaren, akademik araştırmalarda büyük ilgi gören konular içerisinde yer almıştır (Clark vd., 2016). Konu hakkında araştırma yapan yazarlar, "işkoliklik" kavramı ile ilgili ortaya koydukları sonuçlarda, bu alanda yapılan araştırma sayılarının artmasına rağmen, konunun kavramsallaştırılması ve ölçülmesi ile ilgili kafa karışıklığının hala devam ettiğini ve ortak bir noktanın yakalanamadığını ifade etmektedir (Sánchez-Medina vd., 2020:3). Dolayısıyla, "işkoliklik" kavramı hakkında önemli sayıda akademik araştırmaya rağmen, üzerinde mutabık kalınan bir tanımlama günümüzde de henüz yapılamamıştır (Harpaz ve Snir, 2003:292; MorenoJimenez vd., 2005; Clark vd., 2016). İşkoliklik kavramı ilk defa 1968 yılında Oates tarafından alkoliklik kavramından yola çıkarak, kontrol edilemeyen ve işe yönelik aşırı düşkünlüğü tanımlamak için türetilmiştir (Mäkikangas vd., 2013:136; Serçeoğlu ve Selçuk, 2016:40). Kavramın İngilizce karşıllı̆ı olan "Workaholism" terimi ise, alkoliklik kavramının İngilizce karşıllğı olan "alcoholism" terimininden esinlenerek türetilmiştir (Machlowitz, 1980; Serçeoğlu ve Selçuk, 2016:40). Oates (1971:11) işkoliklik kavramını, sürekli çalışma zorunluluğu veya kontrol edilemeyen ihtiyaç olarak tanımlamıştır. Oates (1971), işkolikliği zorlayıcı ve kontrol edilemeyen karakteri nedeni ile alkolizme benzer şekilde, işçinin davranışında gözlemlenen bir davranış türü olarak açıklamaktadır. Bu durumun aynı zamanda, bireyin kişisel sağlığı, mutluluğu, kişilerarası ilişkileri ve sosyal kapasitesi açısından risk oluşturabileceğini ortaya koymuştur. Cherrington (1980) işkolikliği, işi dışında meslek bulamayan insanları karakterize eden, aşırı çalışmaya yönelik irrasyonel bir tercih olarak tanımlamaktadır. Machlowitz (1980) ise işkoliklikleri, işlerine her zaman durumun gerektirdiğinden daha fazla zaman ve düşünce ayıran insanlar olarak tanımlamaktadır. Bazı araştırmacılar ise, çalışma saatlerini dikkate alarak bir tanımlama yapmıştır. Örneğin Mosier'e (1983) göre, haftada en az 50 saat çalışan bir birey "işkolik" olarak tanımlanmıştır. Killinger (1991) işkolikliği, iş görenin zorunlu bir onay ve başarı arayışında kontrol ve güç bağımlılığına dönüşen duygusal istikrarının, kademeli olarak kaybı olarak tanımlamaktadır. Spence ve Robins (1992) ise işkoliklik kavramını, bireyin düşük dereceli iş zevki ile birlikte, yüksek derecede azimli ve işe dâhil olan kişilik yapısı olarak tanımlamaktadır. Spence ve Robins'in bu tanımlaması ve ortaya koydukları model, işkolik çalışmalarında en çok alıntı yapılan modellerden biridir ve günümüzde de bu konudaki ana referanslardan biri olmaya devam etmektedir. Bu araştırmacılar, farklı işgücü tipolojilerini tanımlamak adına, çalışanların profillerinin oluşturabileceği üç ölçülebilir değişken sunmaktadır. Bunlar; işkolik birey, düşük dereceli iş zevki ve yüksek derecede azimli/işe dâhil olan kişi yapılarıdır (Spence ve Robins, 1992). Buna göre, işkolik bireylerin düşünme zamanının büyük bir bölümünü işiyle ilgili konular oluşturmaktadır. Ayrıca, işkolik bireyler işyerindeki görevleri için daha fazla zaman planlaması yaparak bu görevlerini yerine getirmede yüksek düzeyde motivasyona sahiptirler ve daha fazla heyecan duymaktadırlar. Benzer şekilde (Snir ve Harpaz, 2004:522) işkolikliği, bir bireyin işle ilgili faaliyetlere ve düşüncelere, dış ihtiyaçlardan kaynaklanmayan sabit ve önemli ölçüde zaman ayırması olarak tanımlamaktadır. Salanova vd., (2008:1) işkoliklik kavramını, esas olarak 
karşı konulamaz bir ihtiyaç veya sürekli çalışma dürtüsü nedeniyle aşırı çalışma ile karakterize edilen psiko-sosyal hasar olarak tanımlamaktadır. Aynı şekilde Schaufeli vd., (2008:2001) işkolikliği, aşırı çalışma eğilimi ve kendini kompülsif çalışmayla gösteren işe takıntılı olma hali şeklinde tanımlamıştır.

Yukarıdaki tanımlamalardan da anlaşıldığı üzere, araştırmacıların "işkoliklik" ile ilgili tanımlamaları çok yönlüdür ve çoğu araştırmacı konunun farklı yönlerini ortaya koymaya çalışmıştır. Dahası, bu kavramı açıklarken ve sınıflandırırken araştırmacılar arasında herhangi bir fikir birliği oluşmamıştır. Bazı araştırmacılar konuyu bir davranış kalıbı olarak görerek (Scottl vd., 1997:313) bağımlılıkla ilişkilendirirken (Porter, 2006:71), bazıları ise onu bir sendrom olarak değerlendirmiştir (Aziz ve Zickar, 2006:53).

Geçmişten günümüze birçok akademisyen, işkolikliği bir bağımlılık olduğu gerçeğinden yola çıarak, konuyu bu perspektifte incelemiş ve ölçekler geliştirmiştir (Clark vd., 2016). Bu araştırmacılar, işkolikliğin dolaylı olarak rol çatışmaları aracılığıyla mutsuzluğa ve tükenmişliğe yol açtı̆̆ını ortaya koymuşlardır. Killinger (1991)'e göre işkolikler iş ve aile ilişkilerinde yakınlaşma problemi yaşarlar. Aynı şekilde, işkolikliğin kişinin aile yaşamıyla negatif ilişkisi olduğu (Snir ve Harpaz, 2004:534) ve iş-aile çatışmalarına yol açtığı (Burke ve MacDermid, 2000:529; Hammer vd., 2003:435; Bakker vd., 2009:31) ortaya konulmuştur. Robinson vd., (2001:409) araştırmalarında, evli işkoliklerin evlilik ilişkilerinde sorun yaşadıklarını, buna göre işkolik bireylerin eşlerinin evlilik doyumlarının düşük ve eşlerine karşı olumlu duygularının zayıf olduğu sonucunu ortaya koymuştur. İşkolikler için çalışma ihtiyacı o kadar abartılıdır ki kimi zaman sağlıklarını tehlikeye atarak, mutluluklarını azaltır ve kişilerarası ilişkilerini ve sosyal işlevselliklerini bozarlar (Bakker vd., 2009; Gorgievski vd., 2010). Moreno-Jimenez vd., (2005:427) işkolikliğin, sosyal ve ekonomik kriterler bağlamında her ne kadar üretkenlik ve performansta artışa yol açtığını belirtseler de çalışanların sağlıkları üzerinde olumsuz etkileri olduğunu da ortaya koymuşlardır. İşkoliklik sonucu ortaya çıkan yoğun çalışma ve fazla mesai (Blair-Loy vd., 2003), uyku sorunlarına, strese ve sağllğın bozulmasına neden olabilmektedir (van Wijhe vd., 2011). Buna göre, işkolik bireyin çalışma saatleri önemli ölçüde arttığından birey işyerine karşı zorunlu bir adanmışlık kazanmakta ve kendini yalnızca işe adanmış olarak hissetmektedir. Böylelikle birey hayatının diğer yönlerinden zevk almamakla birlikte, bu durum zamanla iş performansında da olumsuz etkilere yol açabilmektedir (Spence ve Robbins, 1992; Porter, 1996; Mudrack ve Naughton, 2001:109). Diğer taraftan Shimazu vd., (2012) çalışmalarının sonuçlarına göre işkolikliğin, iş refahı ve iş performansı ile negatif ilişkili bir kavram olduğu ortaya konulmuştur. Burke'nin (1999) yöneticiler üzerinde gerçekleştirdiği araştırmasının sonuçları, işkoliklik ile iş/kariyer tatmini ve kariyer beklentileri arasında olumsuz ilişki ve işten ayrılma niyetiyle olumlu bir ilişki olduğunu göstermiştir. Andreassen’a (2014) göre, işkoliklik ile bozulmuş sağllk ve refahın yanı sıra, iş ve aile hayatı arasındaki çatışmalarla ilişki bulunmaktadır.

\section{Yenilikçi İş Anlayışı}

Günümüz iş dünyası daha küresel ve daha entegre hale geldikçe, rekabet ortamı büyük ölçüde değişmekte geleneksel yapıdaki işletmeler yeni kurulmuş şirketlere karşı rekabet edemez duruma gelmektedir. Bu durumdan kurtulmanın tek yolu ise, günümüz şartlarına uymaktan ve geleceğin şartlarını önceden yakalamaktan geçmektedir. Çalışanların yenilikçi tutum ve davranışları, günümüz rekabet koşulları altında faaliyet göstermeye çalışan işletmeler için kritik bir konu haline gelmiştir. Bu nedenle, yenilikçilik uzun zamandır ekonomik kalkınmanın ve ticari büyümenin en önemli kaynağı olarak görülmektedir. İşletmelerde yeniliğin nasıl 
geliştirileceği konusu ise hem yöneticiler hem de girişimcilerin dikkatini çekmektedir (Öberg, 2018).

Yenilik ve yenilikçilik, günümüz işletmelerin rekabet avantajı sağlamaları ve büyümeleri için öne çıkan itici bir güçtür (Demirci vd., 2014:1-5). Sürekli değişen ve gelişen dünyada işletmeler çevresel faktörlerden daha fazla etkilenir hale gelmişlerdir. Bununla birlikte işletmelerin rekabet yarışından başarılı olarak çıkabilmeleri ve örgütlerini farklı ve verimli kılmalarının yolu, yenilikçi ve yaratıcı bir iş anlayışından geçmektedir. Çağdaş işletmeler, örgüt içerisinde yenilikçi davranışlara büyük önem vermekte, örgüt içinde yaygınlaşmasını sağlayacak güçlü bir örgüt kültürü oluşturmak istemektedirler. Bu nedenle, yenilik ve yenilikçilik günümüz işletmelerinde örgütsel başarı ve devamlılık için yaşamsal bir öneme sahip bir olgudur (Çalışkan, 2013: 90-94; Pınar ve Arıkan, 2015:66; Bülbül, 2017:44). Bu durum onların ürün, hizmet ve süreç üretiminde ve yönetiminde sürekli yenilikler yapmalarını, çevreye ve gelişmelere uyum sağlamalarını gerekli kılmaktadır. İşletmelerin gerçekleştirecekleri yeniliklerde devamlılık ve tutarlılık göstermeleri, dikkat etmesi gereken bir diğer husustur (Özbağ, 2012:157). Böylece örgütler yenilik yaparak hem performanslarını artırmakta hem de daha dinamik bir yapıya kavuşarak rekabet avantajı sağlamaktadırlar (Özbă̆, 2012:146; Kızıloğlu ve İbrahimoğlu, 2013:106).

Zhong vd., (2018) yenilikçi davranışı, bireyin yeni fikirleri uygulamaya koyma süreci de dahil olmak üzere, orijinal ve potansiyel olarak yararlı fikirler üretme yeteneği olarak tanımlamaktadır. Li ve Zheng'e göre (2014) yenilikçi davranış, çalışanların yenilikçi düşünme stillerini kullanmalarına ve müşteri talebindeki değişikliklere hızlı ve doğru bir şekilde yanıt vermelerine olanak tanıyan, kişisel ve kurumsal performansı artırmak için bir organizasyonda yenilikçi düşüncenin oluşturulması, teşvik edilmesi ve uygulanması olarak tanımlamaktadır. $\mathrm{Bu}$ davranış, yeni problem çözme yöntemleri oluşturma sürecidir ve sorunu tanımlama, soruna çözüm bulma ve bu çözümleri işletmede uygulamakla başlamaktadır (Derin ve Gökçe, 2016). Yenilikçi iş anlayışı, yenilikçi fikirleri geliştirip bu fikirleri ürün ve süreçler olarak somutlaştırabilen örgüt çalışanlarının, tutum ve becerilere yönelik anlayışını gösteren davranışlardır. Örgütlerde çalışanlarda yenilikçi iş anlayışı geliştirmek ve yenilikçi bir örgüt kültürü oluşturmak için, yeni ve farklı yaklaşımların önemsenerek ödüllerle desteklenmesi, iş görenlerin işlerini yapmada ve fikirlerini ifade etmede daha özgür ve esnek yaklaşılması ve çalışanlarının eğitiminin desteklenmesi gerekmektedir. Ayrıca; kaynak dağıtımında yenilikçi fikir ve projelere daha fazla pay verilmesi, ekip çalışmasına önem vererek çalışanların ortak fikir üretmesine fırsat tanınması, ortak bir vizyonun paylaşılması, katılımcı ve destekleyici bir liderlik anlayışının olması gibi unsurlar ve uygulamalar da etkili olmaktadır (Özbağ, 2012:158; Pınar ve Arıkan, 2015:74).

\section{İş Tatmini}

Literatürde iş tatmini, çalışanların yaptığı işten, işyerinden, iş çevresinden, yöneticilerinden, birlikte çalıştığı ekipten ve genel olarak örgütten elde etmeye çalıştığı, rahatlatıcı ve huzur verici bir duygu olarak tanımlanmaktadır (Çarıkçı, 2000; Akıncı, 2002; Karaduman, 2002:70). İş tatmini hakkında en yaygın tanım Locke (1976) tarafından yapılmış olup, kişinin iş veya iş deneyimlerinin değerlendirilmesinden kaynaklanan zevkli veya olumlu bir duygusal durum olarak ifade edilmiştir. İş tatmini bilişsel, duygusal ve davranışsal boyutları olan geniş, karmaşık ve çok bileşenli bir kavramdır (Hulin vd., 2003). Bu açıdan iş tatmini kavramını, bireyin iş deneyimini veya çalışma yaşamının kalitesini etkileyen bir unsur olarak, geniş bir yelpazede incelemek gerekmektedir. İş tatmini kavramın, bireyin genel refahı, iş stresi, işte kontrol, ev-iş dengesi ve çalışma koşulları gibi diğer temel faktörlerle birlikte ve ilişkili olarak değerlendirmek uygun olacaktır (Tomazevic vd., 2014). 
Spector'a (1997) göre bireylerin iş tatmininin 14 ortak yönü bulunmaktadır. Bunlar; takdir, iletişim, iş arkadaşları, yan haklar, iş koşulları, işin doğası, organizasyon, kişisel gelişim, politikalar, prosedürler, terfi fırsatları, tanınma, güvenlik ve denetim olarak sıralanmıştır. İş tatmini, örgütlerde bağlılık, iş kalitesi ve performansın artmasından, işten ayrılma, stres ve tükenmişliğin azalmasına kadar birçok konuda olumlu katkı sağlayan bir kavramdır. Örgütlerde iş tatminsizliği ise işe geç gelme, verimsizlik ve işten ayrılma gibi örgüt açısından maliyetli sonuçlara neden olabilmektedir. İş tatmini, motivasyonda olduğu gibi içsel ve dişsal nedenlerden sağlanabilmektedir (Çarıkçı, 2000; Akıncı, 2002; Üçüncü, 2016:11). İş tatminin en önemli özelliklerinden birisi de zihinsel olmaktan çok duygusal bir kavram olmasıdır. Tatmin olma duygusu ancak birey tarafından hissedilebilir ve onun iç huzura ulaşmasına katkı sağlayabilir (İscan ve Timuroğlu, 2007). Yaygın bir araştırma bulgusu ise, iş tatminin yaşam doyumu ile ilişkili olduğudur (Rain, 1991).

Yapılan akademik çalışmalar neticesinde, işkoliklik kavramının örgütlerdeki yeri ve önemine vurgu yapılarak, yenilikçilik ve yenilikçi iş anlayışı ve iş tatmini gibi kavramlarla yakından ilişkisi olduğu sonucuna varılmıştır. Buna göre işkoliklik kavramını araştıran yazarlar, bu durumun hem olumlu hem de olumsuz sonuçlar doğurabileceğini savunmuşlardır. Liang ve $\mathrm{Chu}$, başarı yönelimi ve mükemmeliyetçiliğin işkoliklik ile ilişkili iki gösterge olduğunu ortaya koymuştur (Liang ve Chu, 2009). Schaufeli vd., (2009:323) göre, işkoliklik bireylerin mutsuzluk ve tükenmişliğine olumlu yönde katkıda bulunmaktadır. Bazı araştırmacılar, kişilik özellikleri ile işkoliklik arasındaki ilişkiyi incelemişlerdir. Örneğin Schwartz (1982:431), işkoliklik ve A Tipi kişilik arasında pozitif bir ilişki bulmuştur. Benzer şekilde Zhdanova vd., (2006), işkoliklik ve mükemmeliyetçilik ile A Tipi kişilik arasında pozitif bir ilişki bulmuştur. Machlowitz (1980), işkolikliğin olumlu bir sonucu olarak iş görenlerin yüksek iş tatminine sahip olduklarını ve bu durumun üretime katkıda bulunarak yüksek performansa yol açtığını savunmuştur. Arsezen ve Kılıçarslan (2017) otel çalışanları üzerinde yaptığı çalışmada, işkoliklik davranışı ile iş tatmini arasında pozitif yönlü bir ilişki olduğunu ortaya koymuştur. Ardıç ve Erbaşaran (2019) tarafından kamu çalışanları üzerinde yapılan çalışmada, istatistiksel olarak anlamlı düzeyde olmasa da işkoliklik ve iş tatmini arasında pozitif bir ilişki saptanmıştır.

Gorgievski vd., (2014) göre, duygusal durumları kontrol ettikten sonra hem işe bağlllık hem de işkoliklik, yenilikçi davranışla doğrudan ve olumlu bir ilişkiye sahiptir. Bayraktaroğlu vd., (2018) göre ise yeniliğe götüren yaratıcı işlerde çalışmak, çalışanlar için oldukça tatmin edici olabilmektedir. İşkoliklik bir yerde tutulduğu sürece, üretkenlik için bir katalizör olabilir. Bir yükseköğretim kurumunda çalışanlar üzerinde yapılan çalışmada katılanlar yüksek düzeyde işkolik olduğunu bildirmişlerdir. Ancak eğitim, iş eğitimi ve iş tatmini ve yeniliklere açık olma açısından işkolik ve yenilikçi insan sermayesi arasında negatif bir ilişki bulunmamıştır. İşkolikliğin insanlar üzerinde pek çok olumsuz etkisi olmasına rağmen, yenilikçi insan sermayesi becerilerinin geliştirilmesi açısından işe bağlılığa iyi bir şekilde hizmet edebileceği ileri sürülmüştür.

\section{YÖNTEM}

\section{Araştırmanın Amacı}

$\mathrm{Bu}$ çalışma, kesitsel ve betimleyici bir araştırmadır. Bu çalışmanın amacl, otel çalışanlarının işkoliklik davranışı ve yenilikçi iş anlayışı düzeylerinin iş tatmini üzerindeki etkisini saptamaktır. Bu amaç kapsamında, otel çalışanlarının sosyo-demografik özellikleri ile işkoliklik davranışları, yenilikçi iş anlayışı ve iş tatmini düzeyleri arasında farklılıklar olup olmadığı da ortaya konulmaya çalışılmıştır. 


\section{Araştırmanın Evreni ve Örneklemi}

Araştırmanın evrenini, Konya ilinde bulunan dört ve beş yıldızlı otel çalışanları oluşturmaktadır. Araştırmanın örneklemini, araştırmaya katılmaya gönüllü olan otellerin ön büro, kat hizmetleri, mutfak, servis, satış-pazarlama ve muhasebe birimlerinde görev yapan ve kolayda örnekleme yöntemi ile seçilmiş toplam 201 otel çalışanı oluşturmuştur. Çalışma, otel çalışanlarıyla yüz yüze anket yöntemiyle gerçekleştirilmiştir. Araştırma verileri Kasım ve Aralık 2019 tarihlerinde toplanmıştır.

\section{Araştırmanın Modeli}

Araştırmanın bağımsız değişkeni işkoliklik ve yenilikçi iş anlayışı, bağımlı değişkeni ise iş tatminidir. Bu araştırmada işkoliklik ve yenilikçi iş anlayışının iş tatmini üzerindeki etkisinin ölçülmesi amaçlanmıştır. Ayrıca katılımcıların sosyo-demografik özelliklerine göre araştırmanın değişkenlerinin farklılık gösterip göstermediği de test edilmiştir. Araştırmanın modeli Şekil 1'de verilmiştir.

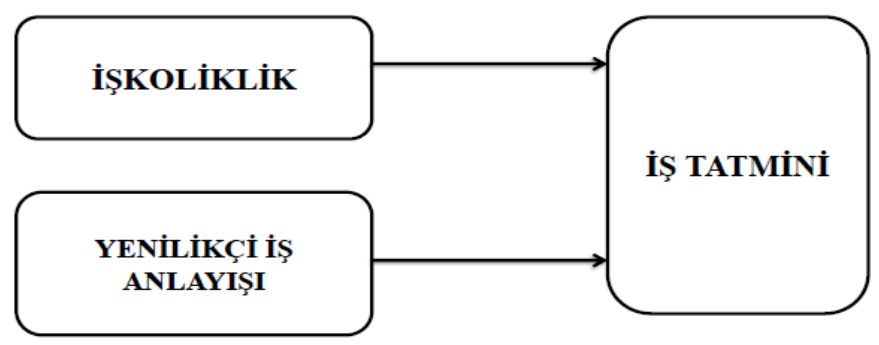

Şekil 1: Araştırmanın modeli

\section{Araştırmanın Hipotezleri}

Araştırmanın modeli kapsamında aşağıdaki hipotezler oluşturulmuş ve test edilmiştir.

$\mathbf{H}_{1}$ : Otel işletmesi çalışanlarının işkoliklik düzeylerinin iş tatminleri üzerinde anlamlı bir etkisi vardir.

$\mathbf{H}_{2}$ : Otel işletmesi çalışanlarının yenilikçi iş anlayışlarının iş tatminleri üzerinde anlamlı bir etkisi vardir.

$\mathbf{H}_{3}$ : Otel işletmesi çalışanlarının işkoliklik ve yenilikçi iş anlayışlarının arasında anlamlı bir ilişki vardir.

$\mathbf{H}_{4}$ : Otel işletmesi çalışanlarının sosyo-demografik değişkenlerine göre işkoliklik düzeylerinde anlamlı bir farklılık vardır.

H5: Otel işletmesi çalışanlarının sosyo-demografik değişkenlerine göre yenilikçi iş anlayışlarında anlamlı bir farklılık vardır.

H6: Otel işletmesi çalışanlarının sosyo-demografik değişkenlerine göre iş tatmini düzeylerinde anlamlı bir farklılık vardır. 


\section{Veri Toplama Araçları}

Anket formu; kişisel bilgi formu (7 soru), "İşkoliklik Ölçeği" (14 soru), "Yenilikçi İş Anlayışı" (9 soru) ve "Minnesota İş Tatmini Ölçeği" (20 soru) olmak üzere dört bölüm ve toplam 50 sorudan oluşmaktadır.

İşkoliklik Ölçeği (Workaholism Scale) kullanılmıştır. Ölçek 5'li Likert şeklinde derecelendirilmiş (1=Hiç Katılmıyorum, 5=Tamamen Katılıyorum) 14 sorudan tek boyuttan oluşan bir ölçektir. Ölçeğin Türkçe formunun geçerlik ve güvenirlik çalışmaları Akın vd., (2013) tarafından yapılmıştır. Ölçeğin Cronbach Alfa iç tutarlılık güvenirlik katsayısı .51 olarak düşük düzeyde bulunmuştur. Doğrulayıcı faktör analizi sonucu, ölçekten faktör yükleri düşük olan 8 madde çıkarılmış, ölçeğin 6 maddesi değerlendirilmeye alınmıştır. Ölçeğin son güvenirlik katsayısı Cronbach Alfa değeri 0,761 olarak güvenilir bulunmuştur. Alpar'a (2000) göre anketin güvenilirliğinin test edilmesinde kullanılan Cronbach Alfa güvenilirlik katsayısı 60-79 arasında olduğunda oldukça güvenilir, 80-100 arasında olduğunda ise ölçek yüksek güvenilirlikte kabul edilmektedir.

Yenilikçi İş Davranışları Ölçeği, Janssen (2000) tarafından geliştirilen ölçek formundan alınarak kullanılmıştır. Ölçek tek boyuttan 9 sorudan oluşan 5'li Likert tarzında derecelendirilmiş (1=Asla, 5=Her zaman) bir ölçektir. Bu ölçekler, Türkiye'de birçok çalışmada kullanılmış ve geçerlilik ve güvenirlilikleri test edilmiştir (Töre, 2019; Yıldırım, 2020; Sezgin vd., 2015; Çıtak, 2017). Doğrulayıcı faktör analizi sonucu, ölçekten faktör yükleri düşük olan 4 madde çıkarılmış, ölçeğin 5 maddesi değerlendirilmeye alınmıştır. Ölçeğin Cronbach Alfa iç tutarlılık güvenirlik katsayısı 0,823 olarak yüksek güvenilir bulunmuştur.

İş tatmini için 20 sorudan oluşan "Minnesota İş Tatmini Ölçeği" kullanılmıştır. Araştırma ölçekleri 5'li Likert şeklinde düzenlenmiştir. Ölçek "İçsel iş tatmini" ve "Dişsal iş tatmini" şeklinde iki faktörden oluşmaktadır. İş tatminini etkileyen içsel faktörler; bireyin kendi özellikleri ve sahip oldukları doğrultusunda ortaya çıkan ve genellikle soyut değerlere ilişkin kazandıkları sonucu oluşan iş tatminini (12 sorudan oluşur); dış faktörler ise bireyin dışındaki unsurların sunduğu ve genellikle maddi ve somut kazançları ortaya koyan iş tatminini (8 sorudan oluşur) ifade etmektedir. Doğrulayıcı faktör analizi sonucu, ölçekten faktör yükleri düşük olan 12 madde çıarılmış, ölçeğin 8 maddesi değerlendirilmeye alınmıştır. Ölçeğin Cronbach Alfa iç tutarlılık güvenirlik katsayısı 0,656 olarak güvenilir bulunmuştur.

Yapılan normal dağılım analizi sonucunda, işkoliklik, yenilikçi iş anlayışı ve iş tatmini ölçeklerinde verilerin normal dağılmadığı $(p<0,005)$ saptanmıştır. Normal dağılımın diğer varsayımları olan ortalama-medyanın birbirine yakınlığı ile basıklık (kurtosis) ve çarpıklığın (skewnes) $-2,+2$ arasında olması gerekliliği açısından incelendiğinde; değişkene göre bu değerlerin normal dağılıma uyduğu görülmüştür. Bu nedenle çalışmada parametrik testlerin kullanılmasına karar verilmiştir.

\section{Veri Analizi ve Verilerin Değerlendirilmesi}

Araştırmada LISREL 8.0 programı yardımıyla doğrulayıcı faktör analizi yapılarak, ölçeklerin geçerliliği araştırılmıştır. Araştırma verileri SPSS 22.0 (Statistical Package for Social Sciences) paket programında değerlendirilmiştir. Veriler, SPSS programında frekans ve yüzde analizleri, iki ortalama arasındaki farkın anlamlılık testi (t-testi), ANOVA testi, Pearson Korelasyon Analizi testi ve Regresyon Analizi testi ile yorumlanmıştır. 


\section{BULGULAR}

Araştırmadan elde edilen sosyo-demografik verilere ve ölçek maddelerine verilen cevaplara ilişkin bulgular aşağıda verilmiştir.

Tablo 1. Sosyo-Demografik Değişkenlere Göre Dağılım

\begin{tabular}{|l|c|c|l|c|c|}
\hline GÖREV YERI & $\mathbf{N}$ & $\mathbf{\%}$ & CINSIIYET & $\mathbf{N}$ & $\mathbf{\%}$ \\
\hline Ön büro & 40 & 19,9 & Kadın & 80 & 39,8 \\
\hline Kat hizmetleri & 31 & 15,4 & Erkek & 121 & 60,2 \\
\hline Mutfak & 29 & 14,4 & Medeni Durum & $\mathbf{n}$ & $\mathbf{\%}$ \\
\hline Servis & 81 & 40,3 & Evli & 45 & 22,4 \\
\hline Pazarlama-Muhasebe & 20 & 10,0 & Bekâr & 156 & 77,6 \\
\hline Yaş & $\mathbf{n}$ & $\mathbf{\%}$ & Eğitim & $\mathbf{n}$ & $\mathbf{\%}$ \\
\hline 18-25 yaş aralığ1 & 122 & 60,7 & İköğretim & 21 & 10,4 \\
\hline 26-35 yaş aralığ1 & 62 & 30,8 & Lise & 55 & 27,4 \\
\hline 36-50 yaş aralı̆̆1 & 17 & 8,5 & Üniversite & 125 & 62,2 \\
\hline Aylık Gelir Durumu & $\mathbf{n}$ & $\mathbf{\%}$ & Mesleki Çalışma Yllı & $\mathbf{n}$ & $\mathbf{\%}$ \\
\hline 2.000-3.500 TL & 188 & 93,5 & $0-5$ yll & 153 & 76,1 \\
\hline 3.501-5.000 TL & 13 & 6,5 & 6-11 yıl & 37 & 18,4 \\
\hline Toplam & $\mathbf{2 0 1}$ & $\mathbf{1 0 0 , 0}$ & $12-20$ yıl & 11 & 5,5 \\
\hline
\end{tabular}

Araştırmaya katılanların sosyo-demografik özellikleri değerlendirildiğinde; katılımcıların \%60,2'sinin erkek, \%77,6'sının bekâr, \%40,3'ünün servis çalışanı; \%62,2'sinin üniversite mezunu, $\% 93,5^{\prime}$ inin aylık gelirinin 2.000-3.500 TL; \%60,7'sinin 18-25 yaş aralığında ve 76,1'inin mesleki çalışma yılının 0-5 yıl olduğu tespit edilmiştir.

Tablo 2. İşkolik Ölçeği Ortalama Puanlamalarının Dağılımı

\begin{tabular}{|l|c|c|c|c|c|}
\hline İşkolik Ölçeği Maddeleri & $\mathbf{N}$ & $\mathbf{M i n}$ & $\mathbf{M a k}$ & Ort. & $\begin{array}{c}\text { Std. } \\
\text { Sapma }\end{array}$ \\
\hline $\begin{array}{l}\text { Yaptığım bir işten hoşlanmasam bile sıkı çalışmak } \\
\text { benim için önemlidir. }\end{array}$ & 201 & 1 & 5 & 3,7313 & 1,07120 \\
\hline $\begin{array}{l}\text { Üstesinden gelebileceğimden çok daha fazlasını } \\
\text { üstlenirim. }\end{array}$ & 201 & 1 & 5 & 3,7264 & 1,04391 \\
\hline $\begin{array}{l}\text { Bir süreliğine işten uzaklaşmak istesem bile kendimi } \\
\text { slklıkla o iş hakkında düşünürken bulurum. }\end{array}$ & 201 & 1 & 5 & 3,5721 & 1,10273 \\
\hline $\begin{array}{l}\text { Bir iş üzerinde çalışmadığım zaman kendimi suçlu } \\
\text { hissederim. }\end{array}$ & 201 & 1 & 5 & 3,4627 & 1,19994 \\
\hline $\begin{array}{l}\text { Bir şeyi yapmak istesem de istemesem de o konuda } \\
\text { çok sıkı çalışmam gerektiğine dair içten gelen bir } \\
\text { zorlama hissediyorum. }\end{array}$ & 201 & 1 & 5 & 3,3881 & 1,16990 \\
\hline $\begin{array}{l}\text { Telaş içinde ve zamana karşı yarışan biri olarak } \\
\text { görünürüm. }\end{array}$ & 201 & 1 & 5 & 3,0597 & 1,22328 \\
\hline Toplam İşkoliklik Düzeyi & $\mathbf{2 0 1}$ & $\mathbf{1}$ & $\mathbf{5}$ & 3,4900 & $\mathbf{0 , 7 6 7 5 1}$ \\
\hline
\end{tabular}


Tablo 2'de İşkoliklik ölçeği maddelerine verilen cevapların puan ortalamaları (1-5) incelendiğinde; işkoliklik düzeyi $(3,4900 \pm 0,76751)$ olduğu tespit edilmiştir. Bu ölçeğin maddeleri bakımından en çok "Yaptığım bir işten hoşlanmasam bile sıkı çalışmak benim için önemlidir" $(3,7313 \pm 1,07120)$, en az "Telaş içinde ve zamana karşı yarışan biri olarak görünürüm" $(3,0597 \pm$ 1,22328) maddelerinin puanlandığ görülmektedir.

Tablo 3. Yenilikçi İş Anlayışı Ölçeği Ortalama Puanlamalarının Dağılımı

\begin{tabular}{|l|c|c|c|c|c|}
\hline Yenilikçi İş Anlayışı Ölçeği Maddeleri & N & Min. & Maks. & Ort. & $\begin{array}{c}\text { Std. } \\
\text { Sapma }\end{array}$ \\
\hline Yeni işlerin geliştirilmesinde çaba gösteririm. & 201 & 1 & 5 & 4,0945 & 0,90334 \\
\hline $\begin{array}{l}\text { Yeni iş metotları, teknikleri ya da araç- } \\
\text { gereçleri araştırıp öğrenirim. }\end{array}$ & 201 & 1 & 5 & 3,9851 & 0,91912 \\
\hline Sorunlara farklı çözümler geliştiririm. & 201 & 1 & 5 & 3,9801 & 0,85417 \\
\hline $\begin{array}{l}\text { İş yürütme konusunda yeni yaklaşımlar } \\
\text { ortaya koyarım. }\end{array}$ & 201 & 1 & 5 & 3,9104 & 0,94443 \\
\hline $\begin{array}{l}\text { İşin uygulanabilmesi için sistematik olarak } \\
\text { yenilikçi fikirler ortaya atarım. }\end{array}$ & 201 & 1 & 5 & 3,8557 & 0,91328 \\
\hline Toplam Yenilikçi İş Anlayışı & 201 & 1 & 5 & $\mathbf{3 , 9 6 5 2}$ & $\mathbf{0 , 6 9 4 1 0}$ \\
\hline
\end{tabular}

Tablo 3'te Yenilikçi İş Anlayışı Ölçeği maddelerine verilen cevapların puan ortalamaları (1-5) incelendiğinde; katılımcıların yenilikçi iş anlayışı düzeyi $(3,9652 \pm 0,69410)$ olduğu saptanmıştır. Bu ölçeğin maddeleri bakımından en çok "Yeni işlerin geliştirilmesinde çaba gösteririm" (4,0945 $0,90334)$, en az "İşin uygulanabilmesi için sistematik olarak yenilikçi fikirler ortaya atarım" $(3,8557 \pm 0,91328)$ maddelerinin puanlandığ görülmektedir.

Tablo 4. Minnesota İş Tatmini Ölçeği Ortalama Puanlamalarının Dağılımı

\begin{tabular}{|l|c|c|c|c|c|}
\hline İş Tatmini Ölçeği Maddeleri & $\mathbf{N}$ & Min. & Maks. & Ort. & $\begin{array}{c}\text { Std. } \\
\text { Sapma }\end{array}$ \\
\hline $\begin{array}{l}\text { Toplumda "saygın" bir kişi olma şansını } \\
\text { bana vermesi bakımından }\end{array}$ & 201 & 1 & 5 & 3,9701 & 1,04360 \\
\hline $\begin{array}{l}\text { Bana sabit bir iş sağlaması bakımından (İş̧ } \\
\text { güvencesi) }\end{array}$ & 201 & 1 & 5 & 3,9055 & 0,99299 \\
\hline $\begin{array}{l}\text { İşimi yaparken kendi yöntemlerimi } \\
\text { kullanabilme şansını bana sağlaması } \\
\text { bakımından }\end{array}$ & 201 & 1 & 5 & 3,8756 & 1,00472 \\
\hline $\begin{array}{l}\text { Başkaları için bir şeyler yapabilme olanağına } \\
\text { sahip olmam bakımından }\end{array}$ & 201 & 1 & 5 & 3,8159 & 0,94918 \\
\hline $\begin{array}{l}\text { Vicdanıma aykırı olmayan şeyler yapabilme } \\
\text { şansımın olması acısından }\end{array}$ & 201 & 1 & 5 & 3,6816 & 1,10368 \\
\hline İçsel İş Tatmini & $\mathbf{2 0 1}$ & $\mathbf{1}$ & $\mathbf{5}$ & $\mathbf{3 , 8 9 9 5}$ & $\mathbf{1 , 0 8 5 0 1}$ \\
\hline $\begin{array}{l}\text { İş ile ilgili alınan kararların uygulanmaya } \\
\text { konması bakımından }\end{array}$ & 201 & 1 & 5 & 3,6915 & 1,02195 \\
\hline İş içinde terfi olanağımın olması bakımından & 201 & 1 & 5 & 3,4328 & 1,25965 \\
\hline $\begin{array}{l}\text { Yaptığım iş ve karşılığında aldığım ücret } \\
\text { bakımından }\end{array}$ & 201 & 1 & 5 & 3,2388 & 1,35007 \\
\hline Dişsal İş Tatmini & $\mathbf{2 0 1}$ & $\mathbf{1}$ & $\mathbf{5}$ & $\mathbf{3 , 4 5 4 4}$ & $\mathbf{0 , 9 5 4 0 8}$ \\
\hline Toplam İş Tatmini & $\mathbf{2 0 1}$ & $\mathbf{1}$ & $\mathbf{5}$ & $\mathbf{3 , 7 0 1 5}$ & $\mathbf{0 , 7 4 6 6 5}$ \\
\hline
\end{tabular}


Tablo 4'de Minnesota İş Tatmini Ölçeği maddelerine verilen cevapların puan ortalamaları (1-5) incelendiğinde; katılımcıların toplam iş tatmini düzeyi $(3,7015 \pm 0,74665)$; içsel iş tatmini düzeyi $(3,8995 \pm 1,08501)$ dışsal iş tatmini düzeyi $(3,4544 \pm 0,95408)$ olduğu saptanmıştır. Bu ölçeğin maddeleri bakımından en çok "Toplumda saygın bir kişi olma şansını bana vermesi bakımından" $(3,9701 \pm 1,04360)$, en az "Yaptığım iş ve karşılığında aldığım ücret bakımından" $(3,2388 \pm 1,35007)$ maddelerinin puanlandığı görülmektedir.

Tablo 5. Katılımcıların Cinsiyet Değişkenine göre İşkoliklik, Yenilikçi İş Anlayışı ve İş Tatmini Düzeyleri

\begin{tabular}{|c|c|c|c|c|c|c|}
\hline Ölçek Boyutları & Cinsiyet & $\mathbf{N}$ & Ort. & SS & $\mathbf{t}$ & $\mathbf{P}$ \\
\hline \multirow[t]{2}{*}{ İşkoliklik } & Kadın & 80 & 3,5021 & 0,78331 & \multirow[t]{2}{*}{0,180} & \multirow[t]{2}{*}{0,857} \\
\hline & Erkek & 121 & 3,4821 & 0,76006 & & \\
\hline \multirow[t]{2}{*}{ Yenilikçi iş anlayışı } & Kadın & 80 & 3,9050 & 0,68545 & \multirow[t]{2}{*}{$-0,999$} & \multirow[t]{2}{*}{0,319} \\
\hline & Erkek & 121 & 4,0050 & 0,69974 & & \\
\hline \multirow[t]{2}{*}{ İş tatmini } & Kadın & 80 & 3,6484 & 0,76775 & \multirow[t]{2}{*}{$-0,818$} & \multirow[t]{2}{*}{0,414} \\
\hline & Erkek & 121 & 3,7366 & 0,73346 & & \\
\hline \multirow[t]{2}{*}{ İçsel iş tatmini } & Kadın & 80 & 3,8425 & 0,74745 & \multirow[t]{2}{*}{$-0,605$} & \multirow[t]{2}{*}{0,546} \\
\hline & Erkek & 121 & 3,9372 & 1,26123 & & \\
\hline \multirow[t]{2}{*}{ Dışsal iş tatmini } & Kadın & 80 & 3,3250 & 0,98079 & \multirow[t]{2}{*}{$-1,569$} & \multirow[t]{2}{*}{0,118} \\
\hline & Erkek & 121 & 3,5399 & 0,93021 & & \\
\hline
\end{tabular}

${ }^{*} \mathrm{p}<0.05,{ }^{* *} \mathrm{p}<0.01$

Araştırma ölçeklerine verilen cevaplar doğrultusunda katılımcıların cinsiyet değişkenine göre işkoliklik, yenilikçi iş anlayışı ve iş tatmini düzeylerinde istatistiksel anlamlılık saptanmamıştır $(\mathrm{p}>0,05)$.

Tablo 6. Katılımcıların Medeni Durum Değişkenine göre İşkoliklik, Yenilikçi İş Anlayışı ve İş Tatmini Düzeyleri

\begin{tabular}{|c|c|c|c|c|c|c|}
\hline Ölçek Boyutları & $\begin{array}{c}\text { Medeni } \\
\text { durum }\end{array}$ & $\mathbf{N}$ & Ort. & SS & $\mathbf{t}$ & $\mathbf{P}$ \\
\hline \multirow[t]{2}{*}{ İşkoliklik } & Evli & 45 & 3,6148 & 0,61835 & \multirow[t]{2}{*}{1,239} & \multirow[t]{2}{*}{0,217} \\
\hline & Bekâr & 156 & 3,4541 & 0,80357 & & \\
\hline \multirow[t]{2}{*}{ Yenilikçi iş anlayışı } & Evli & 45 & 4,1733 & 0,64611 & \multirow[t]{2}{*}{2,409} & \multirow[t]{2}{*}{$0,018^{*}$} \\
\hline & Bekâr & 156 & 3,9051 & 0,69781 & & \\
\hline \multirow[t]{2}{*}{ İş tatmini } & Evli & 45 & 3,8972 & 0,74824 & \multirow[t]{2}{*}{1,997} & \multirow[t]{2}{*}{$0,050^{*}$} \\
\hline & Bekâr & 156 & 3,6450 & 0,73896 & & \\
\hline \multirow[t]{2}{*}{ İçsel iş tatmini } & Evli & 45 & 4,2889 & 1,78710 & \multirow[t]{2}{*}{2,778} & \multirow[b]{2}{*}{$0,006^{* *}$} \\
\hline & Bekâr & 156 & 3,7872 & 0,74546 & & \\
\hline \multirow[t]{2}{*}{ Dışsal iş tatmini } & Evli & 45 & 3,6148 & 0,94803 & \multirow[t]{2}{*}{1,287} & \multirow[t]{2}{*}{0,202} \\
\hline & Bekâr & 156 & 3,4081 & 0,95383 & & \\
\hline
\end{tabular}

${ }^{*} \mathrm{p}<0.05,{ }^{* *} \mathrm{p}<0.01$

Araştırma ölçeklerine verilen cevaplar doğrultusunda, katılımcıların medeni durum değişkenine göre işkoliklik, yenilikçi iş anlayışı ve iş tatmini düzeyleri incelendiğinde; işkoliklik düzeyi ile medeni durum arasında istatistiksel anlamlı farklılığın olmadığı $(p>0,05)$; yenilikçi iş anlayışı ve 
iş tatmini ile medeni durum arasında istatistiksel anlamlı bir farklılığın olduğu $(p<0,05)$ saptanmıştır.

Evlilerin bekârlardan daha fazla düzeyde yenilikçi iş anlayışı ve iş tatminine sahip olduğu görülmektedir. Ayrıca evlilerin bekârlardan daha yüksek içsel tatmin düzeyine sahip olduğu $(p<0,01)$; dışsal iş tatmini düzeyinde ise medeni duruma göre istatistiksel olarak anlamlı bir farklılı̆̆ın olmadığı görülmektedir ( $p>0,05)$.

Tablo 7. Katılımcıların Görev Yeri Değişkenine göre İşkoliklik, Yenilikçi İş Anlayışı ve İş Tatmini Düzeyleri

\begin{tabular}{|c|c|c|c|c|c|c|}
\hline Ölçek Boyutları & Görev Yeri & $\mathbf{N}$ & Ort. & SS & $\mathbf{F}$ & $\mathbf{P}$ \\
\hline \multirow[t]{6}{*}{ İşkoliklik } & Ön büro & 40 & 3,3667 & ,73302 & \multirow[t]{6}{*}{0,839} & \multirow[t]{6}{*}{0,502} \\
\hline & Kat hizmetleri & 31 & 3,6237 & ,71617 & & \\
\hline & Mutfak & 29 & 3,6437 & 69682 & & \\
\hline & Servis & 81 & 3,4568 & ,76865 & & \\
\hline & $\begin{array}{l}\text { Pazarlama- } \\
\text { Muhasebe }\end{array}$ & 20 & 3,4417 & 99012 & & \\
\hline & Toplam & 201 & 3,4900 & ,76751 & & \\
\hline \multirow{6}{*}{$\begin{array}{l}\text { Yenilikçi iş } \\
\text { anlayışı }\end{array}$} & Ön büro & 40 & 3,9350 & 63470 & \multirow[t]{6}{*}{2,965} & \multirow[t]{6}{*}{$0,021^{*}$} \\
\hline & Kat hizmetleri & 31 & 4,2258 & ,54097 & & \\
\hline & Mutfak & 29 & 4,0828 & ,57450 & & \\
\hline & Servis & 81 & 3,7951 & ,79055 & & \\
\hline & $\begin{array}{l}\text { Pazarlama- } \\
\text { Muhasebe }\end{array}$ & 20 & 4,1400 & 61250 & & \\
\hline & Toplam & 201 & 3,9652 & 69410 & & \\
\hline \multirow{6}{*}{ İş tatmini } & Ön büro & 40 & 3,6938 & ,68287 & \multirow{6}{*}{0,526} & \multirow{6}{*}{0,717} \\
\hline & Kat hizmetleri & 31 & 3,8347 & 69551 & & \\
\hline & Mutfak & 29 & 3,7155 & 64771 & & \\
\hline & Servis & 81 & 3,6265 & ,79340 & & \\
\hline & $\begin{array}{l}\text { Pazarlama- } \\
\text { Muhasebe }\end{array}$ & 20 & 3,7938 & ,90346 & & \\
\hline & Toplam & 201 & 3,7015 & ,74665 & & \\
\hline \multirow{6}{*}{ İçsel iş tatmini } & Ön büro & 40 & 3,8650 & 69782 & \multirow[t]{6}{*}{1,460} & \multirow[t]{6}{*}{0,216} \\
\hline & Kat hizmetleri & 31 & 4,3226 & 2,07569 & & \\
\hline & Mutfak & 29 & 3,8276 & ,61114 & & \\
\hline & Servis & 81 & 3,7852 & 80485 & & \\
\hline & $\begin{array}{l}\text { Pazarlama- } \\
\text { Muhasebe }\end{array}$ & 20 & 3,8800 & ,97635 & & \\
\hline & Toplam & 201 & 3,8995 & 1,08501 & & \\
\hline \multirow[t]{6}{*}{ Dişsal iş tatmini } & Ön büro & 40 & 3,4083 & ,91361 & \multirow[t]{6}{*}{0,555} & \multirow[t]{6}{*}{0,695} \\
\hline & Kat hizmetleri & 31 & 3,5591 & ,97139 & & \\
\hline & Mutfak & 29 & 3,5287 & ,84758 & & \\
\hline & Servis & 81 & 3,3621 & 1,03037 & & \\
\hline & $\begin{array}{l}\text { Pazarlama- } \\
\text { Muhasebe }\end{array}$ & 20 & 3,6500 & ,86163 & & \\
\hline & Toplam & 201 & 3,4544 & ,95408 & & \\
\hline
\end{tabular}

\footnotetext{
* $\mathrm{p}<0.05$
} 
Araştırma ölçeklerine verilen cevaplar doğrultusunda, katılımcıların görev yeri değişkenine göre işkoliklik, yenilikçi iş anlayışı ve iş tatmini düzeyleri incelendiğinde; işkoliklik düzeyi ve iş tatmini düzeyi ile görev yeri arasında istatistiksel anlamlı farklılığın olmadığı $(p>0,05)$; yenilikçi iş anlayışı ile görev yeri arasında istatistiksel anlamlı bir farklılı̆̆ın olduğu $(p<0,05)$ saptanmıştır. Kat hizmetlerinde çalışanların servis hizmetlerinde çalışanlara göre daha fazla düzeyde yenilikçi iş anlayışına sahip olduğu görülmektedir.

Tablo 8. Katılımcıların Yaş Değişkenine göre İşkoliklik, Yenilikçi İş Anlayışı ve İş Tatmini Düzeyleri

\begin{tabular}{|c|c|c|c|c|c|c|}
\hline Ölçek Boyutları & Yaş Aralığ & $\mathbf{N}$ & Ort. & SS & $\mathbf{F}$ & $\mathbf{P}$ \\
\hline \multirow[t]{4}{*}{ İşkoliklik } & $18-25$ & 122 & 3,4276 & 79194 & \multirow[t]{4}{*}{2,681} & \multirow[t]{4}{*}{0,071} \\
\hline & $26-35$ & 62 & 3,5054 & ,74717 & & \\
\hline & $36-50$ & 17 & 3,8824 & ,54571 & & \\
\hline & Toplam & 201 & 3,4900 & ,76751 & & \\
\hline \multirow{4}{*}{$\begin{array}{l}\text { Yenilikçi iş } \\
\text { anlayışı }\end{array}$} & $18-25$ & 122 & 3,8508 & ,71562 & \multirow[t]{4}{*}{5,215} & \multirow[t]{4}{*}{$0,006^{* *}$} \\
\hline & $26-35$ & 62 & 4,0903 & 62166 & & \\
\hline & $36-50$ & 17 & 4,3294 & ,61213 & & \\
\hline & Toplam & 201 & 3,9652 & 69410 & & \\
\hline \multirow{4}{*}{ İş tatmini } & $18-25$ & 122 & 3,5789 & 75978 & \multirow[t]{4}{*}{5,638} & \multirow[t]{4}{*}{$0,004^{* *}$} \\
\hline & $26-35$ & 62 & 3,8226 & ,65660 & & \\
\hline & $36-50$ & 17 & 4,1397 & ,76404 & & \\
\hline & Toplam & 201 & 3,7015 & ,74665 & & \\
\hline \multirow{4}{*}{ İçsel iş tatmini } & $18-25$ & 122 & 3,7311 & ,77043 & \multirow[t]{4}{*}{9,436} & \multirow[t]{4}{*}{$0,001^{* *}$} \\
\hline & $26-35$ & 62 & 3,9581 & 66887 & & \\
\hline & $36-50$ & 17 & 4,8941 & 2,69083 & & \\
\hline & Toplam & 201 & 3,8995 & 1,08501 & & \\
\hline \multirow[t]{4}{*}{ Dişsal iş tatmini } & $18-25$ & 122 & 3,3251 & ,99444 & \multirow[t]{4}{*}{3,450} & \multirow[t]{4}{*}{$0,034^{*}$} \\
\hline & $26-35$ & 62 & 3,5968 & ,81903 & & \\
\hline & $36-50$ & 17 & 3,8627 & ,97936 & & \\
\hline & Toplam & 201 & 3,4544 & ,95408 & & \\
\hline
\end{tabular}

* $\mathrm{p}<0.05$

Araştırma ölçeklerine verilen cevaplar doğrultusunda, katılımcıların yaş değişkenine göre işkoliklik, yenilikçi iş anlayışı ve iş tatmini düzeyleri incelendiğinde; işkoliklik düzeyi ile yaş değişkeni arasında istatistiksel anlamlı farklılığın olmadığ 1 ( $>0,05)$; yenilikçi iş anlayışı ve iş tatmini ile yaş değişkeni arasında istatistiksel anlamlı bir farklılığın olduğu $(p<0,01)$ saptanmıştır. 36-50 yaş grubunda olanların 18-25 yaş grubunda olanlara göre daha fazla düzeyde yenilikçi iş anlayışına ve iş tatminine sahip olduğu görülmektedir.

Araştırma ölçeklerine verilen cevaplar doğrultusunda, katılımcıların mesleki çalışma yılı değişkenine göre işkoliklik, yenilikçi iş anlayışı ve iş tatmini düzeyleri incelendiğinde; işkoliklik düzeyi ile yaş değişkeni arasında istatistiksel anlamlı farklılığın olduğu $(p<0,05)$; yenilikçi iş anlayışı ve iş tatmini ile mesleki çalışma yılı değişkeni arasında istatistiksel anlamlı bir farklılığın olmadığı (p>0,05) saptanmıştır. 12-20 yıl arası mesleki çalışma yılına sahip olanların, 0-5 yıl arası olanlara göre daha fazla düzeyde işkoliklik düzeyine sahip olduğu görülmektedir. 
Tablo 9. Katılımcıların Mesleki Çalışma Yılı Değişkenine göre İşkoliklik, Yenilikçi İş Anlayışı ve İş Tatmini Düzeyleri

\begin{tabular}{|c|c|c|c|c|c|c|}
\hline Ölçek Boyutları & $\begin{array}{l}\text { Mesleki } \\
\text { Çalışma Y1lı }\end{array}$ & $\mathbf{N}$ & Ort. & SS & $\mathbf{F}$ & $\mathbf{P}$ \\
\hline \multirow[t]{4}{*}{ İşkoliklik } & $0-5$ yıl & 153 & 3,4161 & 82210 & \multirow[t]{4}{*}{3,180} & \multirow[t]{4}{*}{$0,044^{*}$} \\
\hline & 6-11 yıl & 37 & 3,6937 & ,53937 & & \\
\hline & $12-20$ yil & 11 & 3,8333 & ,30732 & & \\
\hline & Toplam & 201 & 3,4900 & ,76751 & & \\
\hline \multirow[t]{4}{*}{ Yenilikçi iş anlayışı } & $0-5$ yil & 153 & 3,9268 & ,72756 & \multirow[t]{4}{*}{1,209} & \multirow[t]{4}{*}{0,301} \\
\hline & 6-11 y1l & 37 & 4,1243 & ,58566 & & \\
\hline & $12-20$ yil & 11 & 3,9636 & ,48841 & & \\
\hline & Toplam & 201 & 3,9652 & ,69410 & & \\
\hline \multirow{4}{*}{ İş tatmini } & $0-5$ yil & 153 & 3,6634 & ,80030 & \multirow[t]{4}{*}{0,905} & \multirow[t]{4}{*}{0,406} \\
\hline & 6-11 y1l & 37 & 3,8007 &, 54043 & & \\
\hline & $12-20$ yil & 11 & 3,8977 & ,51179 & & \\
\hline & Toplam & 201 & 3,7015 & 74665 & & \\
\hline \multirow{4}{*}{ İçsel iş tatmini } & $0-5$ y1l & 153 & 3,8745 & 1,20871 & \multirow[t]{4}{*}{0,170} & \multirow[t]{4}{*}{0,844} \\
\hline & 6-11 yıl & 37 & 3,9838 &, 51936 & & \\
\hline & $12-20$ y1l & 11 & 3,9636 &, 57144 & & \\
\hline & Toplam & 201 & 3,8995 & 1,08501 & & \\
\hline \multirow[t]{4}{*}{ Dışsal iş tatmini } & $0-5$ yil & 153 & 3,4205 & ,99983 & \multirow[t]{4}{*}{0,801} & \multirow[t]{4}{*}{0,450} \\
\hline & 6-11 y1l & 37 & 3,4955 & 83748 & & \\
\hline & $12-20$ yil & 11 & 3,7879 & ,58258 & & \\
\hline & Toplam & 201 & 3,4544 & ,95408 & & \\
\hline
\end{tabular}

${ }^{*} \mathrm{p}<0.05,{ }^{* *} \mathrm{p}<0.01$

Tablo 10. Katılımcıların İşkoliklik, Yenilikçi İş Anlayışı Düzeyleri ve İşs Tatmini Arasındaki İlişki

\begin{tabular}{|l|l|r|r|r|}
\hline \multicolumn{2}{|l|}{} & İşkoliklik & \multicolumn{1}{c|}{$\begin{array}{c}\text { Yenilikçi İş } \\
\text { Anlayışı }\end{array}$} & \multicolumn{1}{|c|}{ İş Tatmini } \\
\hline \multirow{2}{*}{ İşkoliklik } & $\begin{array}{l}\text { Pearson } \\
\text { Correlation }\end{array}$ & &, $442^{* *}$ &, $462^{* *}$ \\
\cline { 2 - 5 } & Sig. (2-tailed) & &, 000 &, 000 \\
\cline { 2 - 5 } & $\mathrm{N}$ & & 201 & 201 \\
\hline \multirow{2}{*}{$\begin{array}{l}\text { Yenilikçi iş } \\
\text { anlayışı }\end{array}$} & $\begin{array}{l}\text { Pearson } \\
\text { Correlation }\end{array}$ &, $442^{* *}$ & &, $491^{* *}$ \\
\cline { 2 - 5 } & Sig. (2-tailed) &, 000 & & 2000 \\
\cline { 2 - 5 } & $\mathrm{N}$ & 201 & \\
\hline$* *$ Korelasyon 0.01 düzeyinde (virgülden sonra 2 basamak) anlamlıdır. & \\
\hline
\end{tabular}

Araştırma ölçeklerine verilen cevaplar incelendiğinde, otel işletmesi çalışanlarının işkoliklik ile yenilikçi iş anlayışı arasında aynı yönlü orta düzey bir ilişki $(\mathrm{r}=0,442)$; işkoliklik ile iş tatmini arasında aynı yönlü orta düzey bir ilişki $(\mathrm{r}=0,462)$; yenilikçi iş anlayışı ile iş tatmini arasında aynı yönlü orta düzey bir ilişki $(\mathrm{r}=0,491)$ olduğu saptanmıştır $(\mathrm{p}<0,01)$. Bu durumda $\mathrm{H}_{3}$ hipotezi kabul edilmiştir. 
Tablo 11. Katılımcıların İşkoliklik Düzeyinin İş Tatmini Üzerindeki Etkisi

\begin{tabular}{|c|c|c|c|c|c|}
\hline $\mathbf{R}$ & $\mathbf{R}^{\mathbf{2}}$ & Düzeltilmiş $\mathbf{R}^{\mathbf{2}}$ & $\mathbf{F}$ & $\boldsymbol{\beta}$ & $\begin{array}{c}\text { Anlamlılık } \\
\text { (ANOVA) }\end{array}$ \\
\hline $\mathbf{0 , 4 6 2}$ & 0,214 & 0,210 & 54,095 & 0,462 & 0,000 \\
\hline
\end{tabular}

(Bağımlı Değişken: İş tatmini, Bağımsız Değişken: İşkoliklik)

Katılımcıların işkoliklik düzeylerinin iş tatmini üzerindeki etkisini ölçmek için yapılan regresyon analizi sonuçlarına göre, otel çalışanların işkoliklik düzeylerinin iş tatmini üzerinde pozitif ve anlamlı bir etkiye sahip olduğu işkolikliğin iş tatmininin \%21,40'lık kısmını açıladığını göstermektedir. Bu sonuca göre $\mathrm{H}_{1}$ hipotezi kabul edilmiştir.

Tablo 12. Katılımcıların Yenilikçi İş Anlayışı Düzeyinin İş Tatmini Üzerindeki Etkisi

\begin{tabular}{|c|c|c|c|c|c|}
\hline $\mathbf{R}$ & $\mathbf{R}^{2}$ & Düzeltilmiş $\mathbf{R}^{2}$ & $\mathbf{F}$ & $\boldsymbol{\beta}$ & $\begin{array}{c}\text { Anlamlılık } \\
\text { (ANOVA) }\end{array}$ \\
\hline $\mathbf{0 , 4 9 1}$ & 0,241 & 0,237 & 63,111 & 0,491 & 0,000 \\
\hline
\end{tabular}

(Bağımlı Değişken: İş tatmini, Bağımsız Değişken: Yenilikçi iş anlayışı)

Katılımcıların yenilikçilik iş anlayışının iş tatmini üzerindeki etkisini ölçmek için yapılan regresyon analizi sonuçlarına göre, otel çalışanların yenilikçi iş anlayışının iş tatmini üzerinde pozitif ve anlamlı bir etkiye sahip olduğu görülmektedir $(\beta=0,491 \mathrm{p}<0,001)$. R2 değerinin 0,241 olması yenilikçi iş anlayışının iş tatmininin \%23,70'lık kısmını açıkladığını göstermektedir. Bu sonuca göre $\mathrm{H}_{2}$ hipotezi kabul edilmiştir.

\section{SONUÇ ve ÖNERILER}

Konya ilinde bulunan dört ve beş yıldızlı otel çalışanları üzerinde gerçekleştirilen bu çalışma, otel çalışanlarının işkoliklik davranışı ve yenilikçi iş anlayışı düzeylerinin iş tatmini üzerindeki etkisini araştırmıştır. Bu amaç kapsamında, otel çalışanlarının sosyo-demografik özellikleri ile işkoliklik davranışları, yenilikçi iş anlayışı ve iş tatmini düzeyleri üzerinde farklılıklar olup olmadığı da ortaya konulmaya çalışılmıştır. Araştırma, otellerin ön büro, kat hizmetleri, mutfak, servis, satış-pazarlama ve muhasebe birimlerinde görev yapan ve kolayda örnekleme yöntemi ile seçilmiş toplam 201 otel çalışanı üzerinde gerçekleştirilmiştir. Araştırmadan aşağıdaki sonuçlar elde edilmiştir.

Araştırmaya katılan otel çalışanlarının işkoliklik düzeyi (3,4900 $\pm 0,76751)$; yenilikçi iş anlayışı düzeyi $(3,9652 \pm 0,69410)$; toplam iş tatmini düzeyi $(3,7015 \pm 0,74665)$; içsel iş tatmini düzeyi $(3,8995 \pm 1,08501)$ dışsal iş tatmini düzeyi $(3,4544 \pm 0,95408)$ olduğu saptanmıştır. Araştırma kapsamında yapılan korelasyon analizi sonucuna göre otel işletmesi çalışanlarının işkoliklik ile yenilikçi iş anlayışı arasında aynı yönlü orta düzey bir ilişki $(r=0,442)$; işkoliklik ile iş tatmini arasında aynı yönlü orta düzey bir ilişki $(\mathrm{r}=0,462)$; yenilikçi iş anlayışı ile iş tatmini arasında aynı yönlü orta düzey bir ilişki $(r=0,491)$ olduğu saptanmıştır $(p<0,01)$. Katılımcıların işkoliklik ve yenilikçi iş anlayışı düzeylerinin iş tatmini üzerindeki etkisini ölçmek için yapılan regresyon analizi sonuçlarına göre, otel çalışanların işkoliklik düzeylerinin $(\beta=0,462 p<0,001)$ ve yenilikçi iş anlayışı $(\beta=0,491 \mathrm{p}<0,001)$ düzeylerinin iş tatmini üzerinde pozitif ve anlamlı bir etkiye sahip olduğu görülmektedir. İşkolikliğin iş tatminini \%21,40'lık kısmını; yenilikçi iş anlayışının da iş 
tatminin \%23,7'lik kısmını açıkladığını göstermektedir. Elde edilen bu sonuçlar, literatür kısmında ifade edilen Machlowitz (1980), Arsezen ve Kılıçarslan (2017) ve Ardıç ve Erbaşaran'nın (2019) çalışmalarının sonuçlarını desteklemektedir.

Araştırmanın sonucu işkoliklik, yenilikçi iş anlayışı ve iş tatmini arasında pozitif yönlü ilişkiler ağının olduğu sonucunu ortaya koymuştur. Bu durum işkoliklik durumunun ve yenilikçi iş anlayışının çalışanların iş tatmini üzerinde olumlu bir etki yaptığını göstermektedir. Bununla birlikte işkoliklik üzerine yapılan diğer çalışmaların ortaya koyduğu çalışanlar üzerinde negatif yönlü etkilerinin dikkate alınması ve bu doğrultuda önlemlerin alınması gerçeği de göz ardı edilmemelidir. Araştırmada ortaya çıkan sonuçlar doğrultusunda otel çalışanları açısından şu öneriler sunulabilir:

- Otel yöneticilerinin ve çalışanlarının, işletmede uzun süre çalışmanın, planlı ve programlı çalışmadan daha fazla katkı sağlayacağı düşüncesinden kurtulmaları ve iş görenlerin sergilediği işkolik davranışın negatif etkilerini azaltmak için planlı ve programlı çalışmaları destekleyici yaklaşım sergilemeleri gerekmektedir.

- İşletmelerde hem yönetici pozisyonunda olup hem de işkolik davranış sergileyen yöneticilerin, astlarına yönelik yıkıcı davranışlarının önlenmesi gerekmektedir.

- İşkolik davranış sergileyen çalışanlara yönelik, başarılı bir iş hayatının sağlanmasında aile ve iş hayatının önemini ortaya koyacak ve destekleyecek eğitimlerin verilmesi gerekmektedir.

- Çalışanların işe alım süreçlerinde kişilik özellikleri iyi analiz edilmeleri, yetenekleri ve uzmanlıkları doğrultusunda psikometrik testler yapılarak işe yerleştirilmeleri gerekmektedir.

- Otel çalışanlarının yenilikçi iş anlayışı kültürüne sahip olmaları için özgür düşünme ve ifade etme imkânlarının artırılması; yenilikçi fikirlerin otel yönetimleri tarafından desteklenmesi ve teşvik edilmesi sağlanmalıdır.

$\mathrm{Bu}$ araştırmanın sonuçları bazı sınırlılıklar çerçevesinde elde edilmiştir. Öncelikle araştırma belirli bir alanda gerçekleştirilmiş olup, Konya'da faaliyet gösteren 4 ve 5 yıldızlı oteller incelenmiştir. Konuyla ilgili olarak farklı ülkelerde, şehirlerde ve sektörlerde yapılacak olan çalışmalar, benzer veya farklı sonuçlar ortaya koyabilir. Günümüze kadar işkoliklik kavramı ile genel örgütsel davranış kavramları arasındaki ilişkiler sıklıkla incelenme fırsatı bulmuştur. Bundan sonraki süreçte işkoliklik kavramının psikoloji, sosyoloji, sosyal psikoloji, antropoloji ve ekonomi kavramları ekseninde etkilerini ortaya koyan araştırmaların yapılması, alan yazına zenginlik katacaktır.

\section{KAYNAKÇA}

Akın, A., Hamedoğlu, M. A., Sarıcam, H., Akın, U., Kılıç, M., Özendir, D. and Bayrakçı, E. (2013). The Validity and Reliability of the Turkish Version of the Workaholism Scale. 2nd International Symposium on Chaos, Complexity and Leadership, 17-19 December 2013, Ankara, Turkey.

Akıncı, Z. (2002). Turizm Sektöründe İşgören İş Tatminini Etkileyen Faktörler: Beş Yıldızlı Konaklama İşletmelerinde Bir Uygulama, Akdeniz Üniversitesi İktisadi ve İdari Bilimler Fakültesi Dergisi, 2(4): 1-25.

Alpar, R. (2010). Applied Statistic and Validation-Reliability, Florida: Detay Publishing.

Andreassen, C. S. (2014). Workaholism: An Overview and Current Status of the Research, Journal of Behavioral Addictions, 3(1): 1-11. 
Ardıç, K. ve Erbaşaran, Z. (2019). İşkoliklik ve İş Tatmini Arasındaki İlişkinin İncelenmesi, Avrasya Sosyal ve Ekonomi Araştırmaları Dergisi, 6(4): 334-346.

Arsezen, P. and Kıliçarslan, U. (2017). Relationship Between Workaholic Behavior and Job Satisfaction of Tourism Industry Employees: Intermediary Role of Emotional Commitment to the Organization, Journal of Social and Humanities Sciences Research, 4(12): 867-882.

Aziz, S. and Zickar, M. J. (2006). A Cluster Analysis Investigation of Workaholism as A Syndrome, Journal of Occupational Health Psychology, 11(1): 52-62.

Bakker, A. B., Demerouti, E. and Burke, R. (2009). Workaholism and Relationship Quality: A Spillover-Crossover Perspective, Journal of Occupational Health Psychology, 14: 23-33.

Bayraktaroğlu, S., Atay, E. and İlhan, H. (2018). Innovative Human Capital and Workaholism as A New HR Strategy? Journal of Economics and Social Research, 5(9): 12-15.

Blair-Loy, M. and Jacobs, J. A. (2003). Globalization, Work Hours, and the Care Deficit Among Stockbrokers, Gender and Society, 17(2): 230-49.

Burke, R. J. and MacDermid, G. (1999). Are Workaholics Job Satisfied and Successful in Their Careers? Career Development International, 4(5): 277-282.

Burke, R. J. (2000). Workaholism Among Women Managers: Personal and Workplace Correlates, Journal of Managerial Psychology, 15: 520-530.

Bülbül, T. (2017). Yenilik Yönetimi, (Editörler) Memduhoğlu, H. B. ve Yılmaz, K.: Yönetimde Yeni Yaklaşımlar içinde (ss.44-73) Ankara: Pegem Akademi.

Cherrington, D. J. (1980). The Work Ethic, New York: American Management Association.

Clark, M. A., Michel, J. S., Zhdanova, L., Pui, S. Y. and Baltes, B. B. (2016). All Work and No Play? A Meta-Analytic Examination of the Correlates and Outcomes of Workaholism, Journal of Management, 42(7): 1836-1873.

Çalışkan, A. (2013). İç Odaklı Örgüt Kültürünün Yenilikçi Davranışa Etkisinde Personel Güçlendirmenin Aracılık Rolü, "İş Güç" Endüstri İlişkileri ve İnsan Kaynakları Dergisi, 15(1): 88-112.

Çarıkçı, İ. H. (2000). Çalışanların İş Tatminlerini Etkileyen Kişisel Özellikler: Süpermarket Çalışanları Üzerinde Bir Araştırma. Süleyman Demirel Üniversitesi İktisadi İdari Bilimler Fakültesi Dergisi, 5(2): 155-168.

Çıtak, S. (2017). Duygusal Zekâ ile Yenilikçi İş Anlayışı Arasındaki İlişki Üzerine Bir Araştırma: Mersin İli Örneği, Yayınlanmamış Yüksek Lisans Tezi, Toros Üniversitesi, Mersin.

Demirci, E., Uzkurt, C., Işık, N., Aluftekin, N., Göktepe, H. ve Akdeve, E. (2014). Yenilik Yönetimi, Eskişehir: Anadolu Üniversitesi Yayını.

Derin, N. and Gökçe S. G. (2016). Are Cyberloafers also Innovators? A Study on the Relationship between Cyberloafing and Innovative Work Behavior. 12th International Strategic Management Conference (ISMC), 28-30 October 2016, Antalya, Turkey.

Dhar, R. L. (2015). Service Quality and the Training of Employees: The Mediating Role of Organizational Commitment, Tourism Management, 46: 419-430.

Drago, R. (2000). Trends in Working Time in the US: A Policy Perspective, Labor Law Journal, 51: $212-18$.

Frese, M. (2008). The Changing Nature of Work, (Editor) Chmiel, N.: in Introduction to Work and Organizational Psychology (pp. 397-414) Oxford: Blackwell Publishing. 
Gorgievski, M. J., Bakker, A. B. and Schaufeli, W. B. (2010). Work Engagement and Workaholism: Comparing the Self-Employed and Salaried Employees, The Journal of Positive Psychology, 5: 8396.

Gorgievski, M. J., Moriano, J. A. and Bakker, A. B. (2014). Relating Work Engagement and Workaholism to Entrepreneurial Performance, Journal of Managerial Psychology, 29(2): 106-121.

Hammer, L. B., Bauer, T. N. and Grandey, A. A. (2003). Work-Family Conflict and Work-Related Withdrawal Behaviors, Journal of Business and Psychology, 17(3): 419-436.

Harpaz, I. and Snir, R. (2003). Workaholism: Its Definition and Nature, Human Relations, 56(3): 291-319.

He, Y., Li, W. and Keung Lai, K. (2011). Service Climate, Employee Commitment and Customer Satisfaction: Evidence from the Hospitality Industry in China, International Journal of Contemporary Hospitality Management, 23(5): 592-607.

Hulin, C. L. and Judge, T. A. (2003). Job attitudes, (Editors) Borman, W. C. at al.: in Psychology: Industrial and Organizational Psychology (pp. 255-276) Hoboken: Wiley.

Işık, C. ve Meriç, S. (2015). Otel Yöneticilerinin Bireysel Yenilikçi Kapsamında Değerlendirilmesi: Van İli Örneği, Girişimcilik ve İnovasyon Yönetimi Dergisi, 4(1): 1-16.

İşcan, Ö. F. ve Timuroğlu, M. K. (2007). Örgüt Kültürünün İş Tatmini Üzerindeki Etkisi ve Bir Uygulama. [Online] https://dergipark.org.tr/tr/download/article-file/30134 [Erişim Tarihi: 28.06.2020].

Janssen, O. (2000). Job Demands, Perceptions of Effort-Reward Fairness, and Innovative Work Behavior, Journal of Occupational and Organizational Psychology, 73: 287-302.

Jung, H. S. and Yoon, H. H. (2016). What Does Work Meaning to Hospitality Employees? The Effects of Meaningful Work on Employees' Organizational Commitment: The Mediating Role of Job Engagement, International Journal of Hospitality Management, 53: 59-68.

Karaduman, A. (2002). Ekip Çalışmasında, Liderin İş Tatmini Üzerindeki Etkisi, Yayımlanmamış Yüksek Lisans Tezi, Atatürk Üniversitesi, Erzurum.

Kastner, M. (2010). Work-Life Balance für Extremjobber, (Editors) Kaiser, S. and Ringlstetter, M.: in Work-Life Balance (pp. 1-27) Berlin: Springer.

Kızıloğlu, M. ve İbrahimoğlu, N. (2013). İç Girişimcilik Olgusunun Yenilik Yapabilme Becerisine Etkisi: Gaziantep'te Faaliyet Gösteren Yenilikçi Örgütlerde Bir Uygulama, Alanya İşletme Fakültesi Dergisi, 5(3): 105-117.

Killinger, B. (1991). Workaholics: The Respectable Addicts, New York: Simon \& Schuster.

Li, X. and Zheng, Y. (2014). The Influential Factors of Employees' Innovative Behavior and the Management Advices, Journal of Service Science and Management, 7: 446-450.

Liang, Y. W. and Chu, C. M. (2009). Personality Traits and Personal and Organizational Inducements: Antecedents of Workaholism, Social Behavior and Personality, 37(5): 645-660.

Locke, E.A. (1976). The Nature and Causes of Job Satisfaction, (Editor) Dunnette, M. D.: in Industrial and Organizational Psychology (pp. 1297-1349) Chicago: Rand McNally.

Machlowitz, M. (1980). Workaholics: Living with Them, Working with Them, New York: AddisonWesley. 
Mäkikangas, A., Schaufeli, W., Tolvanen, A. and Feldt, T. (2013). Engaged Managers are not Workaholics: Evidence from a Longitudinal Personcentered Analysis, Journal of Work and Organizational Psychology, 29(3): 135-143.

Moreno-Jiménez, B., Gálvez-Herrera, M., Garrosa-Hernández, E. and Rodríguez-Carvajal, R. (2005). La Adicción al Trabajo, Psicologia Conductual, 13(3): 417-428.

Mosier, S. K. (1983). Workaholics: An Analysis of their Stress, Success and Priorities, Unpublished Masteral Thesis, University of Texas, Austin.

Mudrack, F. E. and Naughton, T. I. (2001). The Assessment of Workaholism as Behavioural Tendencies: Scale Development and Preliminary Empirical Testing, International Journal of Stress Management, 8(2): 93-111.

Oates, W. E. (1971). Confessions of a Workaholic: The Facts about Work Addiction, New York: World Publishing Company.

Öberg, C. and Alexander A. T. (2018). The Openness of Open Innovation in EcosystemsIntegrating Innovation and Management Literature on Knowledge Linkages, Journal of Innovation\&Knowledge, 69: 1-10.

Özbağ, G. K. (2012). Örgüt İkliminin Yeniliğe Destek Algısı Üzerindeki Etkilerini Belirlemeye Yönelik Bir Araştırma, Dokuz Eylül Üniversitesi İktisadi İdari Bilimler Fakültesi Dergisi, 27(2): 145161.

Pınar, İ. ve Arıkan, C. (2015). Örgütsel Öğrenme Yeteneği ile Örgütsel Yenilik Arasındaki İlişki: Tekstil Sektöründe Bir Araştırma, İstanbul Üniversitesi İşletme Fakültesi Dergisi, 44(2): 65-76.

Porter, G. (1996). Organizational Impact of Workaholism. Suggestions for Researching the Negative Outcomes of Excessive Work, Journal of Occupational Health Psychology, 1: 70-84.

Rain, J. S., Lane, I. M. and Steiner, D. D. (1991). A Current Look at the Job Satisfaction/Life Satisfaction Relationship: Review and Future Considerations, Human Relations, 44(3): 287-307.

Robinson, B. E., Carroll, J. J. and Flowers, C. (2001). Marital Estrangement, Positive Affect and Locus of Control among Spouses of Workaholics and Spouses of Nonworkaholics: A National Study, American Journal of Family Therapy, 29: 397-410.

Salanova, M., Del Líbano, M., Llorens, S., Schaufeli, W.B. and Fidalgo, M. (2008). La adicción al trabajo (Workaholism), Nota Técnica de Prevención, 759(22): 1-6.

Sánchez-Medina, A. J., Arteaga-Ortiz, J., Naumchik, R. M. and Pellejero, M. (2020). The Intention to Quit Entrepreneurship in Tourism SMEs: The Effect of Work Addiction, International Journal of Hospitality Management, 89: 1-12.

Schabracq, M. J. and Cooper, C. L. (2000). The Changing Nature of Work and Stress, Journal of Managerial Psychology, 15(3): 227-41.

Schaufeli, W. B., Taris, T. W. and Van Rhenen, W. (2008). Workaholism, Burnout and Engagement: Three of a Kind or Three Different Kinds of Employee Well-Being? Applied Psychology, 57(2): 173-203.

Schaufeli, W.B., Shimazu, A. and Taris, T.W. (2009). Being Driven to Work Excessively Hard: The Evaluation of a Two-Factor Measure of Workaholism in the Netherlands and Japan, CrossCultural Research, 43(4): 320-348.

Schwartz, H. S. (1982). Job Involvement as Obsession- Compulsion, Academy of Management Review, 7(3): 429-432. 
Scottl, K. S., Moore, K. S. and Miceli, M. P. (1997). An Exploration of the Meaning and Consequences of Workaholism, Human Relations, 50(3): 287-314.

Serçeoğlu, N. ve Selçuk, G. N. (2016). Konaklama İşletmelerinde Çalışan Personelin İşkoliklik Eğilimleri ile Hizmet Odaklılık İlişkisi: TRA1 Bölgesinde Bir Araştırma, Turizm Akademik Dergisi, 3(1): 39-55.

Sezgin, O. B., Uçar, Z. ve Duygulu, E. (2015). Güven, Yenilikçi İş Davranışı İlişkisinde Bilgi Paylaşımının Aracılık Rolü, Dokuz Eylül Üniversitesi Isşletme Fakültesi Dergisi, 16(2): 1-20.

Shimazu, A., Schaufeli, W. B., Kubota, K. and Kawakami, N. (2012). Do Workaholism and Work Engagement Predict Employee Well-being and Performance in Opposite Directions? Industrial Health, 50(4): 316-321.

Snir, R. and Harpaz, I. (2004). Attitudinal and Demographic Antecedents of Workaholism, Journal of Organizational Change Management, 17: 520-536.

Spector, P. E. (1997). Job Satisfaction: Application, Assessment, Causes and Consequences, Thousand Oaks: SAGE.

Spence, J. and Robbins, A. (1992). Workaholism: Definition, Measurement, and Preliminary Results, Journal of Personality Assessment, 58: 160-178.

Tang, Y., Shao, Y. F. and Chen, Y. J. (2019). Assessing the Mediation Mechanism of Job Satisfaction and Organizational Commitment on Innovative Behavior: The Perspective of Psychological Capital, Frontiers in Psychology, 10: 1-12.

Tomazevic, N., Seljak, J. and Aristovnik, A. (2014). Factors Influencing Employee Satisfaction in the Police Service: The Case of Slovenia, Personnel Review, 43(2): 209-227.

Töre, E. (2019). Entelektüel Sermayenin Yenilikçi İş Davranışına Etkisinde Bilgi Paylaşımının Aracı Rolü, Çanakkale Onsekiz Mart Üniversitesi Yönetim Bilimleri Dergisi, 17(34): 275-485.

Üçüncü, K. (2016). İş Tatmini ve Motivasyon. [Online] https://docplayer.biz.tr/18176069-Is-tatminive-motivasyon.html [Erişim Tarihi: 26.06.2020].

van Beek, I., Taris, T. W. and Schaufeli, W. B. (2011). Workaholic and Work Engaged Employees: Dead Ringers or Worlds Apart? Journal of Occupational Health Psychology, 16(4): 468-482.

Van Wijhe, C., Peeters, M. and Schaufeli, W. (2011). Understanding Workaholism and Work Engagement: The Role of Mood and Stop Rules, Career Development International, 16(3): 254-270.

Walz, S. M. and Niehoff, B. P. (2000). Organizational Citizenship Behaviors: Their Relationship to Organizational Effectiveness, Journal of Hospitality \& Tourism Research, 24(3): 301-319.

Yıldırım, S. K. (2020). Otel İşletmelerinde Bilgi Paylaşımının Yenilikçi İş Davranışına Etkisinde Dönüştürücü Liderliğin Aracılık Rolü, Journal of Tourism and Gastronomy Studies, 8(1): 137-157.

Zhdanova, L., Allison, L. K., Pui, S. Y. and Clark, M. A. (2006). A Meta-Analysis of Workaholism Antecedents and Outcomes. SIOP Conference, 5-7 May 2006, Dallas, U.S.A.

Zhong, Z., Hu, D., Zheng, F., Ding, S. and Luo, A. (2018). Relationship between InformationSeeking Behavior and Innovative Behavior in Chinese Nursing Students, Nurse Education Today, 63: $1-5$. 